\title{
HOW DO THE BRAND-ORIENTED SMES COMMUNICATE?
}

\author{
Rohana Mijan ${ }^{1}$ \\ Senior Lecturer of Integrated Marketing Communication, \\ Universiti Utara Malaysia, School of Multimedia Technology and Communication, \\ College of Arts and Sciences, 06010 Universiti Utara Malaysia, Sintok, Kedah, Malaysia. \\ Phone number: +604 9286478. Email: rohana.mijan@uum.edu.my \\ Noor Aziah Abdullah ${ }^{2}$ \\ Senior Lecturer of Media and Law, \\ Universiti Utara Malaysia, School of Multimedia Technology and Communication, \\ College of Arts and Sciences, 06010 Universiti Utara Malaysia, Sintok, Kedah, Malaysia. \\ Phone number: +604 9286478. Email: nooraziah@uum.edu.my
}

Received date: $12-10-2019$

Revised date: $31-10-2019$

Accepted date: 16-12-2019

Published date: 29-12-2019

To cite this document: Mijan, R., \& Abdullah, N. A. (2019). How Do the Brand-Oriented SMEs Communicate? International Journal of Law, Government and Communication, 4(17), 71-79. DOI: $10.35631 / \mathrm{ijlgc} .417007$

\begin{abstract}
Brand development has become an essential strategy in delivering messages of the brand. It is synonymous with a brand-oriented company but not SMEs. Lack of resource awareness has influenced SMEs to ignore the potential of internal resources and focus more on financial in carrying out branding activities. This is in contrast with the brand-oriented company where they had utilising their internal brand resources to maximise communication activities. Besides the communication strategy, companies also communicate through branding strategy by adopting brand resources as medium and message. The communication process occurs in conjunction with the ongoing branding strategy. These approaches had given an option to SMEs to focus on internal resources and not relying on financial solely. Further empirical research also recommended.
\end{abstract}

Keywords: Communication, Branding, Brand Orientation, Small And Medium-Sized Enterprises

\section{Introduction}

Building strong brands have become an important issue for many organisations. Brand development becomes one of the main strategies to build a strong brand. Brand development referred to the activity that focuses on branding. However, branding synonymous with the brand-oriented company, company that adopting strategic brand resources as the main resource in branding but not SMEs. SMEs often associated with resource barriers due to the lack of internal resource awareness. As consequences SMEs tend to rely on advertising activities which is more financial-based and because of this, the communication activities are limited (Wong \& Merrilees, 2008). 
There are specific ways to communicate without depending much on financial resources such as utilising the strategic brand resources like brand name, personality and culture. Strategic brand resources represent the tangible and intangible company's resources (De Chernatony, 1999; Wernerfelt, 1989). The brand-oriented company had utilised these resources to create a communication medium to deliver rational and emotional brand messages (Urde, 1999). Strategic brand resources become a source to create a meaningful relationship with the employees and customers. The brand development strategy based on strategic brand resources helped SMEs to expand their communication strategies and not rely on financial resources only.

Therefore, the objective of this paper is to discuss the option of communication tools for SMEs to develop their brand. In the section the following an overview of the relevant literature about brand development, particularly on strategic brand resources. The concept of communication is defined and its relationship with SMEs and brand-oriented company branding is discussed. Finally, the conclusion is presented, and future research suggested.

\section{Literature Review}

\section{Brand Development, Strategic Brand Resources and Marketing Communication}

A brand has been described as an agent of different owned by a company. In parallel with the business development, the brand evolved from a static definition which is only tangible elements such as symbols and visual to intangible elements such as symbolic and emotional brand or a combination of both elements (Santos-Vijande et al., 2012). Some of the brands' definitions are also tailored according to the nature of the company, such as SMEs. For example, according to Ojasalo et al (2008), the brand is representative of the brand management system such as objective, resources, communication and brand building process. Every planning and implementation of the brand development process will symbolise a brand of the company. The energetic brand can be created through branding.

In the beginning, branding is an activity that delivers a tangible brand message only (Landa, 2006). However, according to Fauziah et al (2012) as the brand consist of tangible and intangible elements, so the branding becomes a medium to spread the messages by utilising these two elements. Branding activities helped the brand to relate with customers in rational and emotional angles. It is more meaningful when companies projected brand as an asset to improve brand equity. According to Davis and Dunn (2002), branding is an integrated company process to develop capabilities by combining the advantages of human resources and product to create a valuable asset for the company and meaningful to customers. Therefore, branding is a brand development process which involves planning; implementing of brand development strategy such utilising brand element through branding strategy and spreading the messages through brand communication strategy; and measuring and monitoring brand performance. It is a company's effort to gain return investments. This article will be focus solely on brand development strategy and these strategies always being related to resources.

Resource means a specific component in the company's drive to become agents of development. It is a basic internal resource for strategy implementation (Grant, 1991) and its controlled entirely by the company to improve efficiency and effectiveness (Daft, 1983). Each company have different resources. The differentiation of the resources among internal and external showed that company owned a strategic resource. Strategic resources referred to the resource 
that capable of creating competitive strategies and sustainably benefiting in the market (Barney, 1991; Wernerfelt, 1989). It has special characters such as valuable, rareness, imitability and substitutability (Barney, 1991). According to Wong and Merrilees (2005), the company need to focus on strategic resources to achieve their goal, especially in volatile markets. A brand also has its strategic resources because of the unique and valuable characters; its brand elements are listed in the company's resources.

A strategic brand resource is the resource that valued to the company and able to create superior values to customer relationships. Previous researchers tend to divide the resource into two categories, tangible and intangible (De Chernatony \& Riley, 1998; Fahy, 2002). It includes the brand name and brand functions; human resources; innovation; internal communications; brand personality; brand culture; social capital; and reputation. These resources are able to align company vision with capabilities and adopt a brand to become an attraction tool to connect customers rationally and emotionally. By utilising brand resources as the primary source for brand development strategy, it will expand communication effects and help to support longterm brand development activities (Abimbola \& Kocak, 2007).

The communication referred to the marketing communication, defined as a company attempting to inform, persuade and remind customers directly or indirectly about the brands they sell (Keller, 2009). It represents the 'voice' of the company and its brands. Keller (2009) divided into eight primary forms which are advertising, sales promotion, events and experiences, public relations and publicity, direct marketing, interactive marketing, word-of-mouth marketing and personal selling. These forms of communication are closed to the customers (Van Riel, 1995) and it can contribute to brand equity by embedded the brand memory and creating a brand image in the market. It will drive to sales points and affect shareholder values (Luo \& Donthu, 2006; Van Riel, 1995). However, it has always been associated with financial resources and it is costly to be implemented (Van Riel, 1995). Due to this, most companies tend to limit their communication strategies. Therefore, the company needs to build its brand in a specific marketing communication environment to deliver brand messages (Keller, 2009) and considers resource availability to implement the relevant forms includes SMEs.

\section{Branding and Communication Strategy in SMEs}

SMEs has an awareness of the importance of branding to the company; however, the practice is vice-versa. SMEs instead focus on daily operations to keep the business running (Ojasalo et al., 2008). Resource constraints are the main problem regarding branding (Odoom et al., 2017; Mitchell et al., 2013) especially financial due to the lack of brand resource awareness (Suhaini \& Noor Hasmini, 2016; Fauziah et al., 2012) which refers to brand development strategies as limited to advertising, name and logo (Razeghi et al., 2014; Wong \& Merrilees, 2005) and its consume a lot of money. As consequences, an intensity of communication strategy is relying on the availability of financial resources.

Thus, to deliver brand messages, SMEs has accessed various medium to reach customers to create brand awareness (Horan et al., 2011). Krake (2005) found that SMEs tend to publish an advertisement in the newspapers, brochures and utilise public relations. However, SMEs emphasises only on brand name and logo in advertising activities (Wong \& Merrilees, 2005). They are less likely to use advertising and sponsoring programs on television. Due to this, SMEs tend to focus on personal selling or face-to-face communication to demonstrate their quality of work (Sandbacka et al., 2013; Ojasalo et al., 2008) even though advertising activities, such as television, yellow pages, and promotional leaflets were important to branding (Wong \& 
Merrilees, 2005). SMEs are using word-of-mouth communication strategies to convey a brand message. The communication form based on human resources seems relevant and practical tools to convey messages; and SMEs rely heavily on these forms (Wong \& Merrilees, 2005).

It is found that SMEs did not raise brand awareness in branding strategy, but rather emphasises in communications strategy (Horan et al., 2011). SMEs focus more on traditional branding strategies such as corporate, product branding and co-branding (Ojasalo et al., 2008; Wong and Merriless, 2005). Interestingly, in communicating SMEs has exploited their brand resources in branding and communication strategies as a medium and messages for brand development. Yet, SMEs instead focus on advertising technicality such as the frequency of the publishing and types of communication channels rather than the strategies of brand resources that can be utilised to attract customers. SME also focuses on tangible brand resources and ignored intangible brand resources. As a result, their communication strategies effect is minimal, and this is different in the brand-oriented company.

\section{Brand Orientation and Its Communication Elements}

The brand-oriented company are very keen on communication activities. There are several characters of brand-oriented companies. It is including brand becomes leading in company development, adopting brand as a strategic resource, focusses on inside-out process in creating a strategy, transparent in facing market volatile and emphasises on a meaningful relationship with stakeholders (Mijan, 2016; Urde, 1999). Due to the internal orientation, they need to communicate to gain information from employees regarding the brand resources strength and weaknesses and retrieve the market information from customers and competitors to relate it with their capabilities.

The communication aspect in brand orientation has been highlighted by several authors such as Urde (1999). According to Urde (1999), brand orientation is an approach in which the processes of the organisation revolve around the creation, development, and protection of brand identity in an ongoing interaction with target customers to achieve lasting competitive advantages in the form of brands. It is highlighted the interaction within the brand development process and the symbol becomes a medium and messages to communicate with customers to protect the brand for a long-term and create competitive advantages.

Meanwhile, Ewing and Napoli (2005) states that to share brand meaning and embedded brand values to the staff, the company requires to give priority to the internal communication and other communication strategies. The internal communication builds trust towards the brand and it will simplify the delivering of brand communication values to the customers. Similarly, Gromark and Melin (2011) emphasises on internal communication to develop a brand value among employees and then communicate to the external stakeholders to create brand equity. Interaction processes are compulsory to build brand value and to be delivered to customers.

Internal communication has been practised in building and delivering value to stakeholders (Gromark \& Melin, 2011; Ewing \& Napoli, 2005). Interaction with customers involving reciprocal relationship and interplay and that is entitle the brand orientation is a continuous process. This communication is an ongoing process to ensure that brand value is created in line with consumer preferences (Gromark \& Melin, 2011). In the brand orientation approach, communication is an essential element to develop brands that satisfy consumer preferences. Internal communications based on brand resources become a basis to connect with external communication. 


\section{Holistic Communication in Brand-Oriented Company}

Communication became the main medium for receiving and delivering brand value to the internal and external contexts (Gromark \& Melin, 2011; Ewing and Napoli, 2005). Even though a brand-oriented company has focused on intrinsic brand value, but they capable of meeting unconditional customers' preferences. Communication processes occur in an ongoing branding strategy (Gromark \& Melin, 2011; Hankinson, 2001b) and using brand resources to develop a branding strategy and communicate to customers.

Some studies show that brand-oriented company are exploiting brand resources to communicate with customers. For example, a study by Bridson and Evans (2004) found that brand function encourages customers to interact with brands, especially about purchase problems and brand presentation toward competitors. They found that the principle of brand orientation has been coordinating communication activities in the company and enables them to deliver the brand core value to customers consistently. Whereas the brand distinctiveness (visuals and symbols) and symbolic (brand personality) do not create communication with the customer, even the company has applied the advertising strategy tools such as artists and music. Their studies found that advertising strategy is capable of delivering brand differentiation but was not able to create communication with customers.

Sequel review from Bridson et al (2013) also found that the brand function often creates communication with customers about the role of the brand such as giving benefit to the customers. Whereas Hankinson (2001b) found the logo and brand visuals can be a medium of communication to attract customers and even more they gain brand information through it. However, Baumgarth (2010) found that brand visual capable of communicating if employee's behaviour supported them. This is because the employee's behaviour toward brand development enables to strengthen visual communication; its will influence customers.

The role of human resources becomes crucial in brand communication. It was found that the company was exploited the role of human resources in communicating with customers. Gromark and Melin (2011) found that in the beginning, the company has built an internal brand value among employees' and then deliver to the customers. Companies maximise their internal communications with employees to develop the brand value and then set the value to the customer. Communication with customers must be reciprocal and continuous to ensure that brand value is created in line with customer preferences.

In contrast, Hirnoven et al (2013) found that the interaction between staff will boost communication effects because it helps to establish brand messages based on resources. A similar message was also communicated to employees and customers. The clarity of these processes creates an effective two-way communication within company and stakeholder (Hirnoven \& Laukkanen, 2013). The study showed that although advertising strategy is effective ways to raise awareness (Reid et al., 2005) yet word-of-mouth contributes higher impact in building lasting relationships with customers. Resource development help to expand the role of communication in the company.

A brand-oriented company started its communication strategy from internal to external. The company has expanded its brand resources to deliver messages and to create a communication platform for branding strategy. The development of brand resources helps the company grow its brand and achieve brand equity (Urde, 1999). The ability to contribute to competitive 
advantages entitles brand resources as an internal asset that is represent the tangible and intangible brand in the market. While most the SMEs ignores their internal resources, particularly brand resources.

\section{Conclusion}

As a conclusion, SMEs owned resources for brand development. The lack of brand resources (Horan et al., 2012) due to unaware of the internal brand resource's potential (Fauziah et al., 2012; Amran et al., 2010). As consequences, it illustrates that SMEs lack the resources to develop the brands. Thus, brand orientation practice provides an option for SMEs to capture opportunities in the market with more consistency and reducing barriers. The priority of internal resources allows them to identify the strength and weakness of the resources that can be developed into a competitive strategy (Mijan, 2016). It has been shown that a company who develops their brand from internal resources enable to create a solid presentation of the company and its brand (Hatch and Schultz, 2003).

Adopting resource development as a medium of communication represent a strategic move to reduce the financial burden among SMEs. Even though advertising activities still impose a burden on SMEs, but the variety of options can be implemented such as utilising social media to promote their brand as it is an influencing communication medium in Malaysia (Siti Ezaleila \& Azizah, 2010), cheaper and practical for current needs (Opoku et al., 2007; Guiling \& Xiaojuan, 2006). Therefore, an exploration of branding practice in social media is suggested for future research to expose the styles, strategies and approaches toward online branding practice.

\section{References}

Abimbola, T. \& Kocak, A. (2007). Brand, organization identity and reputation: SMEs as expressive organizations: A resources-based perspective. Qualitative Market Research: An International Journal, 10(4), 416-430. doi.org/10.1108/13522750710819748

Amran, H., Kassim, M., Wahid, A., Igau, A. O. \& Hassan, M. H. (2010). Managing local brands in facing challenges of globalization: Be a local or global leader? 1-10. Retrieved from http://www.repo.uum.edu.my

Barney, J. B. (1991). Firm resources and sustained competitive advantage. Journal of Management, 17(1), 99-120. doi 10.1177/014920639101700108

Baumgarth, C. (2010). Living the brand: Brand orientation in the business-to-business sector. European Journal of Marketing, 44(5), $653 \quad-\quad 671$. doi.org/10.1108/03090561011032315

Bridson, K. \& Evans, J. (2004). The secret to a fashion advantage is brand orientation. International

Journal of Retail and Distribution Management, 32(8), 403-411. doi.org/10.1108/09590550410546223

Bridson, K. Evans, J., Mavondo, F. \&Minkiewicz, J. (2013). Retail brand orientation, positional advantage and organizational performance. The International Review of Retail, Distribution and Consumer Research, 23(3), 245-264. doi: 10.1080/09593969.2013.776991

Daft, R. L. (1983). Learning the craft of organizational research, The Academy of Management Review, 8(4), 539-549. doi 10.2307/258255

Davis, S. M. \& Dunn, M. (2002). Building the brand-driven business. California: Jossey-Bass. 
De Chernatony, L. (1999). Brand management through narrowing the gap between brand identity and brand reputation. Journal of Marketing Management, 15(1-3), 157-179. doi.org/10.1362/026725799784870432

De Chernatony, L. \& Riley, F. D. O. (1998). Modelling the components of the brand. European Journal of Marketing, 32(11), 1074-1090. doi.org/10.1108/03090569810243721

Ewing, M.T. \& Napoli, J. (2005). Developing and validating a multidimensional nonprofit brand orientation scale. Journal of Business Research, 58, 841-853. doi: 10.1016/j.jbusres.2003.09.012

Fahy, J. (2002). A resource-based analysis of sustainable competitive advantage in a global environment. International Business Review, 11, 57-78. doi.org/10.1016/S09695931(01)00047-6

Fauziah S.A., Rosmini O., Siti Zaleha A. R., \& Muslim A. (2012). Leadership branding for sustainable customer engagement, International Journal of Social and Human Sciences, 6. Retrieved from http://waset.org/.../leadership-branding-for-sustainable-customerengagement

Grant, R. (1991). The resource-based theory of competitive advantage: Implication for strategy formula. California Management Review, 33(3), 114. doi.org/10.2307/41166664

Gromark, J. \& Melin, F. (2011). The underlying dimensions of brand orientation and its impact on financial performance. Journal of Brand Management, 18(6), 394-410. doi: 10.1057/bm.2010.52;

Guiling \& Xiaojuan (2006). The brand management status and development research of SME in China. Retrieved from http://www.seiofbluemountain.com/upload/product/200911/2006zxqyhy11a14.pdf.

Hankinson, P. (2001b). Brand orientation in the charity sector: A framework for discussion and research. International Journal of Nonprofit and Voluntary Sector Marketing, 6(3). doi.org/10.1002/nvsm.149

Hatch, M.J. \& Schultz, M. (2003). Bringing the corporation into corporate branding. European Journal of Marketing, 37(7/8), 1041 - 1064. doi.org/10.1108/03090560310477654

Hirnoven, S. \& Laukkanen, T. \& Reijonen, H. (2013). The brand orientation-performance relationship: An examination of moderation effects. Journal of Brand Management, 119. doi: $10.1057 / \mathrm{bm} .2013 .4$

Hirvonen, S. \& Laukkanen, T. (2013). Brand orientation in small firms: an empirical test of the impact on brand performance. Journal of Strategic Marketing, doi: 10.1080/0965254X.2013.819372

Horan, G., O'Dwyer, M. \& Tiernan, S. (2011). Exploring management perspectives of branding in service SMEs. Journal of Services Marketing, 25(2), 114-121. doi.org/10.1108/08876041111119831

Keller, K. L. (2009). Building strong brands in a modern marketing communications environment. Journal of Marketing Communications, 15(2-3), 139-155. doi: org/10.1080/13527260902757530

Krake, F. B. G. J. M. (2005). Successful brand management in SMEs: A new theory and practical hints. Journal of Product and Brand Management, 14(4), 228-238. doi.org/10.1108/10610420510609230

Landa, R. (2006). Designing Brand Experiences. Australia: Wadsworth.

Laukkanen, T., Nagy, G., Hirnoven, S., Reijonen, H. \& Pasanen, M. (2013). The effect of strategic orientations on business performance in SMEs: A multigroup analysis comparing Hungary and Finland. International Marketing Review, 30(6), 510-535. doi 10.1108/IMR-09-2011-0230 
Luo, X. \& Donthu, N. (2006). Marketing's credibility: A longitudinal investigation of marketing communication productivity and shareholder value. Journal of Marketing 70(4), 70-91. d doi.org/10.1509/jmkg.70.4.70

Mijan, R. (2016). Resource exploration in brand-oriented company: A conceptual model. Journal of Global Business and Social Entrepreneurship, 1(1), 68-78.

Mitchell, R., Hutchinson, K. \& Quinn, B. (2013). Brand management in small and mediumsized (SME) retailers: A future research agenda. Journal of Marketing Management. doi: 10.1080/0267257X.2013.798672

Odoom, R., Narteh, B., \& Boateng, R. (2017). Branding in small- and medium-sized enterprises (SMEs): Current issues and research avenues. Qualitative Market Research: An International Journal, 20(1), 68-89. doi:10.1108/QMR-12-2015-0091

Ojasalo, J., Nätti, S. \& Olkkonen, R. (2008). Brand building in software SMEs: An empirical study. Journal of Product and Brand Management, 17(2), 92-107. doi.org/10.1108/10610420810864702

Opoku, A.O., Abratt, R., Bendixen, M. \& Pitt, L. (2007). Communicating brand personality: Are the websites doing the talking for food SMEs? Qualitative Market Research: An International Journal, 10(4), 362-374. doi.org/10.1300/J156v08n02_03

Park, S.I \& Kim M.J. (2013). Does brand orientation matter? An empirical study in Korean SMEs. Asia Marketing Journal, 14(4), 117-142.

Urde, M., Baumgarth,.C. \& Merrilees, B. (2013). Brand orientation and market orientation From alternatives to synergy. Journal of Business Research, 66, 13-20. doi: 10.1016/j.jbusres.2011.07.018

Urde, M. (1999). Brand orientation: A Mindset for building brands into strategic resource. Journal of Marketing Management, 15(1-3), 117-133. doi.org/10.1362/026725799784870504

Razeghi, Y., Roosta, A., Alemtabriz, A. \& Gharache, M. (2014). The role of corporate brand in the entrepreneurial SMEs total brand. International Business and Management, 8(2), 120-130. doi:10.3968/4666.

Reid, M., Luxton, S. \& Mavondo, F. (2005). The relationship between integrated marketing communication, market orientation and brand orientation. Journal of Advertising, 34(4), 11-23. doi 10.1080/00913367.2014.934938

Sandbacka, J., Natti, S. \& Tahtinen, J. (2013). Branding activities of a micro industrial services company. Journal of Services Marketing, 27(2), 166-177. doi: 10.1108/08876041311309270]

Santos-Vijande, M.L., Ana Belén del Río-Lanza, A. B., Suárez-Álvarez, L., Díaz-Martín, A.M. (2012). The brand management system and service firm competitiveness. Journal of Business Research. doi: org/10.1016/j.jbusres.2012.07.007

Siti Ezaleila, M. \& Azizah, H. (2010). Media sosial: tinjauan terhadap laman jaringan sosial dalam talian tempatan. Jurnal Pengajian Media Malaysia, 12(2), 37-52. Retrieved from http://repository.um.edu.my/9524/1/JPMM2010_No2_Final

Suhaini, M.D., \& Noor Hasmini, A.G. (2016). A review of branding benefits among small and medium sized enterprises (SMEs). Available from http://repo.uum.edu.my/16315/1/19.pdf Van Riel, C.B.M. (1995). Principles of Corporate Communication. Prentice-Hall: London.

Wernerfelt, B. (1989). From critical resource to corporate strategy. Journal of General Management, 14(3).

Wong, H.Y. \& Merrilees, B. (2008). The performance benefits of being brand-oriented. Journal of Product and Brand Management, 17(6), 372-383. doi.org/10.1108/10610420810904112 
Wong, H.Y \& Merrilees, B. (2005). A Brand orientation typology for SMEs: A case research approach. Journal of Product and Brand Management, 14(3), 155-162. doi $10.1108 / 10610420510601021$ 